УДК: 72.012

DOI: $\underline{\text { https://doi.org/10.24867/02FA01Grbic }}$

\title{
ИМПЛЕМЕНТАЦИЈА СЛОБОДНОСТОЈЕһИХ ДРВЕНИХ ЗВОНИКА У СРПСКИМ МАНАСТИРИМА
}

\section{THE IMPLEMENTATION OF FREE-STANDING WOODEN BELFRIES IN SERBIAN MONASTERIES}

\author{
Милош Грбић, Факултет техничких наука, Нови Сад
}

\section{Област - АРХИТЕКТУРА}

Кратак садржај - Предмет истраживања овог рада су звоници и манастирске иелине. Свакако они представљају два одвојена предмета истраживања, али их је готово немогуће ни раздвојити. Њихово међусобно укритавање и сједињавање кроз историју их представља као нераскидиву (манастирску) иелину која је уједно, свака за себе, самостална и посебна тема испитивања којима сам се бавио у раду. Задатак истраживања овог рада је поновно спајање, које је кроз историју раздвојено, ове две иелине у једну, у виду имплементације, кроз архитектонску студију, нових осмишљених слободностојећих дрвених звоника у манастирске целине, у сврси оживљавања оба, једно кроз друго.

Кључне речи: Звоници, манастири, духовност, конструкција, историја

\begin{abstract}
The subjects of this study are the bell towers and monasteries. Certainly they represent two separate subjects of research, but it is almost impossible to separate them. Their mutual cross-cutting and unification through history presents them as an inseparable (monastery) whole, which, at the same time, is an independent and special topic of study that I have dealt with in my work. The task of researching this paper is to reconnect, which has been separated through history, these two parts into one, in the form of implementation, through an architectural study, newly designed freestanding wooden belfries to the monasteries, for the purpose of reviving both, one through the other.
\end{abstract}

Key words: Bell towers, monasteries, spirituality, construction, history

\section{1. УВОД}

Резултати истраживања овог рада доказују оправданост идеје и смисла циља имплементације слободностојећих дрвених звоника. Реч је о изузетно обимном и пространом истраживању, уз своје напоре и публикације којих и даље није довољно, оно је и даље недовољно проучавано. У претходном раздобљу, истраживања су икључиво била усмерена ка црквеним грађевинама.

\section{НАПОМЕНА:}

Овај рад проистекао је из мастер рада чији ментор је била проф. др Мигјана Сладић.
Читави делови манастирских целина, као и њихови елементи су у вековном континуитету константно обнављани , преграђивани, мењани, изнова грађени и рушени, најчешће насилно, па су једино манастирске цркве дочекале савремено доба у приближно првобитном архитектонском обличју. Пројектовање нових звоника је у циљу поновног подизања, односно враћања, само једног од сегмената изгубљене манастирске целине, у виду обнављања те целине ка својем временом изгубљеном обиму. Она се може једино испунити поновним стварањем свих осталих делова манастира. До тада, моја жеља је да овим истраживањем, зазвоним на позив у почетак „васкрсења” целокупне манастирске пуноће.

\section{2. ЗВОНИК}

Звоник је елемент у архитектури, јавног карактера, углавном самосталан или саставни део другог објекта. Представља вишефункционални архитектонско- конструктивни склоп. Неке најважније функције које има су: информациона функција, функција обележавања територије, контрола те територије, архитектонска функција, функција комуникације"[1]. "Звоник има неколико својстава или намера. Означава, наглашава, разликује се у простору. Издваја се висином, звуком, архитектуром. Његов садржај је наглашен јер се углавном налази на почетку верског комплекса" [1]. У јавној архитектури, намењен је за друштво у целини, а посебно на отвореном простору, што представља најједноставнији елемент знака, чији наставак, развој и коначни облик представља звоник.

\section{3. АРХИТЕКТУРА МАНАСТИРА}

Архитектура манастира средњовековне Србије подразумева целокупно градитељство стварано у православним манастирским насељима насталим од 12. До 15. века у држави Стефана Немање, његових наследника, обласних господара, и најзад, у деспотовини у 15. веку. Архитектура манастира средњовековне Србије је блиско везана за развој византијског манастира а самим тим и шире, за манастире хришћанског истока. Развој манастира и манастирске архитектуре у средњовековној Србији не иде увек напоредо са државним црквеним развојом. Понекада парадоксално, при распаду једног облика државности - Душанове царевине - и стварању другог- деспотовине- манастири задржавају своју 
функцију, дајући стваралачко - архитектонском погледу нов квалитет.

За време Турских освајања, као тип храма се уводи црква триконосне основе. Ова архитектура, створена на познатим предлошцима који се налазе на Светој Гори, делатности у касном средњем веку. То је раздобље у коме се граде велики манастири у земљама обласних владара, од којих градитељство на подручјима Лазара Хребељановића представља највиши домет."Ограђени простор- манастир има неколико функција који га одређују. У главним цртама могу се издвојити три наменске групе: зона култа, зона становања и економска зона. Манастирска црква у скоро свим манастирима средњовековне Србије заузима средишње - централно место у насељу.

Друга врста грађевине са одређеном култном функцијом јесте манастирска трпезарија. Њен положај је у извесном смислу одређен црквеним објектом, са обзиром да се после главне службе из цркве одлазило у трпезарију. Важан елемент просторне организације, чији положај одређује његова намена, јесте главни манастирски улаз. Он се, такође, у већини случајева налази у западном делу манастирског обзиђа, наспрам главног црквеног улаза, обезбеђујући непосредну комуникацију са црквом" [2].

У архитектури манастира издвајају се две битно различите категорије. Једној припадају сакралне грађевине, чији се архитектонски смисао темељи на типским предлошцима и њиховим варијантама са одеређеним симблочним значењем, а другој световна здања, лишена симблочке надградње, сведена на основни градитељски језик. "Те две категорије живе истовремено, као антиподи : стално- духовно, и променљиво-световно.

Процес стварања одређеног архитектонског облика је сматран коначним тек у јединству са сликаним унутрашњим простором" [3]. Украшавање световних здања било је свакако прилагођено одабраној функцији. Најпре је реч о сликаном украсу на спољним и унутрашњим зидовима. Да су спољни зидови цркава били живописани, позната је пракса у Византијској, али и српској средњовековној средини.

\section{4. КРИТЕРИЈУМИ И ОПРАВДАНОСТИ}

\section{1 Критеријуми за одабир имплементације}

Архитектонско - градитељски - Архитектура и градитељство српских манастира се разликује у односу на временске периоде, односно стилове. Сваки период и стил имају своја достигнућа у складу са својим условима које пружају. Највиши архитектонско - градитељски домени свакога од историсјких периода су концизно образложени.

Доказ за то, да су од најизузетнијег архитектонско градитељског значаја, представља чињеница да се сва остала архитектура тог периода градила на основу типологија таквих првобитно осмишљених манастира, односно није превазиђена.
Територијални - Сходно томе да су на различитим територијама Србије и изван ње деловали различити историсјки утицаји, манастирске целине нису свугде задржале исте манастирске сегменте. Углавном насилно рушени и разарани манастирски сегменти су у појединим регијама обновљени, док су на неким територијама остали необновљени и обрнуто. Звоници, као делови манастирске целине, са својим вишеструким функцијама, такође постоје и непостоје у зависности од места. У циљу што шире обнове и територијалне заступљености поновно изграђених звоника, бирани су манастири у што већем регионалном опсегу, од севера ка југу, као и изван граница земље.

Историјски - Историју чине њени догађаји. У зависности од догађаја који су се дешавали, место догађаја добија на историјском значају. Историјски значај наших манастира је несумњив за сваки од њих понаособ. Међутим, не могуће је не нагласити и не издвојити манастире у којима су се одиграли најважнији догађаји за српску државу, цркву, народ, духовност, уметност и тако даље. Ти догађаји су јасно дефинисани и стопљени са појединим манастирима које због њих имају епитет темеља српске духовности.

Временски - Најважнији временски период је свакако и период почетка и развитка спрске манастирске архитектуре, односно средњовековни период. Међутим, неизоставно је не поменути Византијски период градње који нам је дао смернице ка нашем, као ни период градње након средњовековне, односно период под Турском владавином. Водећи се свеобухватном историјом манастирске архитектуре изабрани су манастири који обухватају сва три, од наведених, периода.

Уметнички - Свако уметничко дело може да се посматра из више углова и да се разуме на више различитих начина. Уметност која се оваплоћава у манастирима а готово у целости кроз цркву, као манастирски главни елемент, припада највреднијем уметничком стваралаштву. Међутим, постоје она манастирска уметничка дела која се својим достигнућем истичу и која су уврштена у дела од изузетног значаја, не умањујући друге значаје, већ истичући свој. Таква дела су окарактерисана у виду највећег домета свога времена и она се могу упоређивати и истицати једино у односу на дела истог времена, односно стила.

Духовни - Слично уметношћу, о истицању духовности појединих манастира је вероватно још незахвалније говорити. Сваки манастир поседује и јесте извориште саме духовности. Усуђујем се једино да направим избор на основу бројчаних података који говоре о броју реликвија, књига, моштију, икона и тако даље.

\section{2 Одабир манастира који оправдавају критеријуме за имплементацију}

Незахвално би било упуштати се у било каква дубља и шира истраживања наших манастира, због велике обимности и извора информација, како би се дошло до конкретнијег оправдања за следећи избор манастирских комплекса који би оправдавали имплемен- 
тацију. Свакако би најидеалније решење било изградити у свим манастирским целинама све изгубљене сегменте који су се налазили на сваким од њих, а поготово слободностојеће дрвене звонике, јер сваки од манастира без изузетка, несумњиво испуњава наведене критеријум. Моје полазиште ка оживљавању манастира кроз звонике је ипак од манастира који се кроз образложене критеријуме истичу као водећи. Следећи манастири највише оправдавају наведене критеријуме за имплементацију слободностојећих дрвених звоника: Крушедол, Пећка патријаршија, Милешева, Жича, Високи Дечани, Грачаница, Студеница, Острог, Хиландар и црква светих апостола Петра и Павла. Имајући у виду да је црква светих апостола Петра и Павла једина црква, међу осталим набројаним манастирским комплексима, са разлогом је сврстана у одабир. Чињенице за то, као и остале оправданости изабраних манастира, су наведене у даљем истраживању којим сам се посветио у наредом поглављу.

\section{5. СРПСКИ МАНАСТИРИ}

Крушедол - Најзначанији манастир на територији Војводине по својем архитектонском издању и историјским догађајима, обнављању од разарања, најлепши иконостас из 16. века (ДЕИЗИС), династији Бранковић, њиховом животу у манастиру и њиховим моштима које се овде налазе, као и гробовима Кнегиње Љубице и Краља Милана Обреновића.

Пећка патријаршија - Сматра се међу најзначајнијим споменицима српске архитектуре и градитељства и чуваром духовности српског народа. Прва Српска патријаршија са престолом првог патријарха у Пећи, многобројна вредна уметничка дела, библиотека Пећке Патријаршије, Ромулово јеванђеље из 14. века, једна од најлепших фресака српске уметности из 16. века - Рођење Христово.

Милешева - Међу најстаријим манастирима Србије, са почетка 13. века, убраја се у најлепша архитектонска здања по узору на Студеницу и Жичу, фреске и сликарство Милешеве су најлепша европска остварења како из 13. века, тако и уопштено и убрајају се у највеће светске домете тога доба, посебно се издваја фреска Белог Анђела, мошти Светога Саве које су се ту налазиле док нису спаљене, у Милешеви се налазила једна од првих Српских штампарија.

Жича - Сматра се после Студенице најлепшим архитектонским здањем за ово доба, убраја се у најстарије манастире, датира из почетка 13. века, представља место можда и најзначајнијих историјских догађаја за Српски народ од којих је свакако крунисање 10 Српских краљева током историје, прво седиште аутокефалне српске архиепископије од аутокефалности Српске православне цркве са Светим Савом на челу, небројано обнављање и подизање од многобројних разарања, репрезентативни примери сликарства овога доба (златно доба српског сликарства).

Високи Дечани - Највећи архитектонски пример споменика средњовековне српске историје на територији Србије и најбоље очувани средњовековни српски манастир, који је изграђен почетком 14. века, на његовој изградњи су радили и сами Стефан Дечански и његов син Цар Душан Силни, са преко 1000 композиција са исто толико и ликова чини фрескосликарство манастира, ризница Високих Дечана сматра се после Хиландарске најбогатијом ризницом, овде почивају мошти Светога Краља Стефана Дечанског, као и Свете Јелене Дечанске.

Грачаница - Представља врхунац архитектонскограђевинског савршенства, Међу најстаријим манастирима са почетка 14. века, Задужбина краља Милутина у коме се налази огроман број композиција са исто толико ликова, фрескосликарство манастира се сматра једним од првокласних остварења овога времена, овде је први пут у српском сликарству насликана усправна разграната лоза Немањића са 16 портрета.

Студеница - Сматра се најлепшим архитектонским издатком због византијско-рашке школе и пределом у којем се налази, један од највећих и најбогатијих манастира српске средњовековне архитектуре, спада у најстарије манастире, изграђен је у 12. веку, колекција фресака из 13. и 14. века, врхунац уметничког обликовања представљају 4 Студеничка портала, ту се налазе неке од највреднијих реликвија и предмета као што су најстарији српски часовник, прстен краља Стефана Првовенчаног, најстарији портрети Стефана Првовенчаног и Вукана Немањића, као и мошти Светог Стефана Немање, Стефана Првовенчаног, Анастасије Немањић, и гроб Вукана Немањића.

Острог - Најтежи подухват и један од најлепших архитектонско-грађевинских захвата у коме је овај манастир изграђен вертикално под 90 степени уз литицу самога врха планине Острошке греде представља изузетан споменик српске духовности и архитектуре, фреске које красе унутрашњост манастира датирају из 17. века, осликане су по природном рељефу стена, најпосећенији српски манастир са чудотворним моштима Светога Василија.

Хиландар - Највећи и најкомплекснији архитектонско-грађевински комплекс Српске духовности и културе, Српско царство на Светој Гори, најзначајније духовно и културно средиште Српског народа, представља најбогатију ризницу и архив средњовековног српског народа, чува се око 3.500 икона, 507 рукописних повеља средњовековних влада, 1.041 уникатни рукопис књига са укупно 312.000 страна, 80 старих штампаних књига од 15. до 17. века, и 40.000 књига од 17. века, па до данас, градитељско наслеђе чине слојеви од 12-17 века, преко 5.000 метара квадратних фрескосликарства,

Ту су и ћивоти са Христовим реликвијама, мошти од више од 100 светаца, два крста састављена од остатака Првобитног крста распећа, делови Трновог венца, Христове трске и огртача, крв Христова, Карејски типик из 1199. Године представља најстарији писани документ манастира Хиландар, икона Богородице тројеручице из 8. века, најстарија Српска библиотека. 
Црква Светих апостола Петра и Павла - Представља најранији израз ранохришћанске, односно византијске архитектуре, односно најстарији споменик црквене архитектуре на простору Србије и првобитно је седиште рашке епископије, потиче из 8 . века али је вероватно и старијег датума, најстарије фреске из њене унутрашњости потичу из 9, 10, 12. и 13. века, неки од најзначајнијих догађаја из периода владавине династије Немањића су везани за ову цркву као што је крштење Стефана Немање, предавање престола Стефану Првовенчаном, монашењем Стефана и Ане, скупоцена и разноврсна археолошка открића, црква је окружена православим гробљем, а ови надгробни споменици представљају најубедљивије сведочанство о животу и деловању људи у прошлости.

\section{6. АРХИТЕКТОНСКА РЕШЕЫА ЗВОНИКА}

Вођен архитектонским концептом складности и контекстуалности усмеравао сам своју архитектуру ка иновативним решењима која неће нарушити манастирски ред али ће стабилно стајати као представници свог времена.

Угледајући се на студије случаја, текстуалне описе и остале садржаје истраживања дрвених слободностојећих звоника, као резултат рада, осмишљена су три репрезентативна модела.

\section{1 Архитектонско решење првог модела}

Полазишта ка решењу првог модела су у смеру проналажења и откривања правилног пропорцијског односа самог звоника, као и његов однос према висинама манастира. Први модел звоника је у основи квадратног облика. Кота пода је издигнута од земље 40 сантиметара ради првенствене заштите од влаге. Издигнутост је решена каменим постољима на које се ослања конструкција.

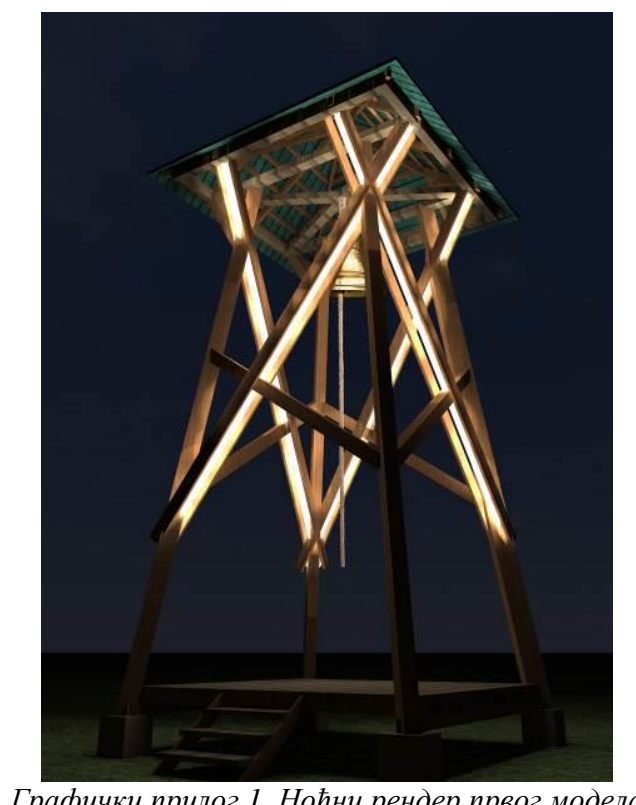

Патос звоника је обрађен фоснама које леже на гредама. Звоник се састоји од четири стуба која су под углом нагнута према центру основе и теже да се додирну у једној тачки ако би се продужили. Укруту стубовима пружају клешта са све четири стране. Она се продужавају и усецају у рожњаче. Ослонац рожњачама су такође и косници који под мањим углом крећу од виших тачака стубова. Кровну конструкцију чине рожњаче и рогови.

Преко рогова су постављене летве на које се закива дрвена шиндра. Основни материјал од којег је склопљен звоник је храстово дрво (може се употребити и орах ) због своје чврстоће и трајности. Детаљи ослонаца при дну стубова и појединих веза су од кованог гвожђа.

Грађа је искључиво тесана због уклапања у манастирски амбијент. Заштита грађе се састоји од противпожарних премаза који неће утицати на структуру и боју дрвета. Расвета је у првом моделу сакривене између клешта.

\section{2 Архитектонско решење другог модела}

Идеја за други модел звоника је настала по узору на заклон, склониште, куће давних времена. Заклон за звоно у овом случају представља транспарентан простор, довољан да задовољи намени. Конструктивни склоп представља истовремено основну и кровну конструкцију. Звоник се састоји од само два пара рогова, један наспрам другог, који се међусобно сустичу. Оба пара рогова су међусобно спрегнута косником. Горња половина рогова је додатно прелетвана и потпомаже укрућењу иако чини подконструкцију за дрвену шиндру.

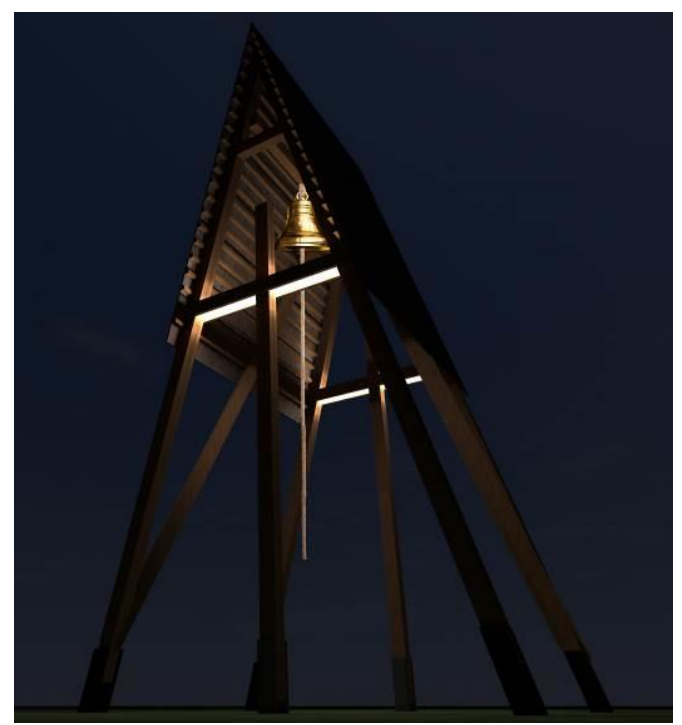

Графички прилог 2. Ноћни рендер другог модела

Чеоне стране су укрућене клештима које заједно са средњим стубом чине крст који надомешта стандардни, на крову. Сходно томе да је циљ овог модела био да се са што мање материјала, односно дрвене грађе, добије довољно изражајна и стабилна конструкција, довољно је било поставити по један пар рогова и по један спрег да задовоље овом приступу. Врста дрвета од којег је склопљен звоник је такође храстово дрво ( може се употребити и орах ) због своје чврстоће и трајности. Детаљи ослонаца при дну 
стубова и појединих веза су од кованог гвожђа. На овом моделу се звоник ослања индиректно на земљу, односно издигнут је плочама од кованог гвожђа које са шрафовима, са једне и друге стране у виду клешта, држе конструкцију.

На тај начин је решено ослањање на земљу без камених блокова или масивних темељења која би, свакако оба случаја, нарушила једноставност и лакоћу конструкције. Грађа је искључиво тесана због уклапања у манастирски амбијент. Заштита грађе се састоји од противпожарних премаза који неће утицати на структуру и боју дрвета.

Расвета је као и управом моделу сакривена између клешта.

\section{3 Архитектонско решење трећег модела}

Истраживањем прва два модела, добијено решење се разликује од претходних богатијим склопом елемената конструкције, као саме композиције односа висине и ширине. То је утицало на повећане ширине и висине звоника у односу на претходна два. Конструктивни склоп је транспарентна просторна структура састављена из два појаса у основи. По вертикали се издвајају такође два појаса, оба завршена кровном конструкцијом.

Решење је базирано на фолклорну архитектуру и њене елементе.

Конструкција овог модела се састоји од четири стуба која су постављена у облику квадрата у основи. Они ce простиру целом висином конструкције и представљају њену окосницу. Стубови пролазе кроз прву кровну раван за коју су везани косницима са по две стране и продужавају се до друге кровне равни за коју имају улогу ослонца. Горњи део стубова, који је изнад првог крова, спрегнут је са све четири стране унакрсним спреговима који су причвршћени челичним плочама са обе стране спрегова.

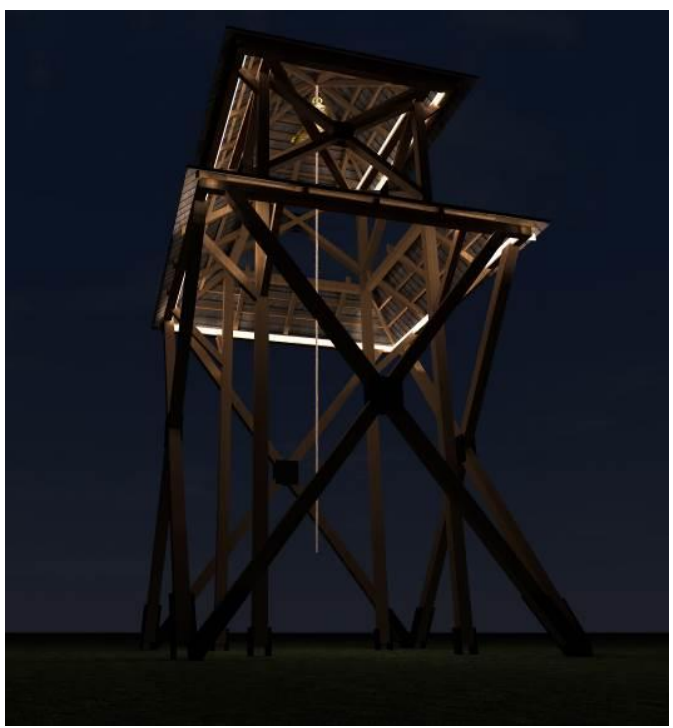

Графички прилог 3. Ноћни рендер трећег модела
Доњу кровну конструкцију носе високи унакрсни спрегови који су међусобно причвршћени на исти начин као и горњи. Они дају потпору и стабилност целој конструкцији. Детаљи ослонаца при дну стубова и појединих веза су од кованог гвожђа. На овом моделу се звоник ослања индиректно на земљу, односно издигнут је плочама од кованог гвожђа које са шрафовима , са једне и друге стране у виду клешта, држе конструкцију. Кровне конструкције се састоје од истих елемената, иста је и расподела оптерећења, као и претхона два модела. Грађа је искључиво тесана због уклапања у манастирски амбијент. Заштита грађе се састоји од противпожарних премаза који неће утицати на структуру и боју дрвета. Расвета је, за разлику од претходна два модела , сакривена по ободу рожњача кровних конструкција.

\section{7. ЗАКЉУЧАК}

Архитектуром усмереном ка иновативним решењима која неће нарушити манастирски ред али ће стабилно стајати као представник свога (овога) времена, спроведено је истраживање које је имало за циљ да оправда идеју и смисао имплементације слободностојећих дрвених звоника у српским манастирима. Реч је била о изузетно обимном и пространом истраживању које је уз све напоре и даље остало недовољно истражено. Циљ ове архитектонске студије је да звоник, као један од сегмената изгубљене манастирске целине врати у манастирске комплексе, али не у виду старијих, зиданих или узиђиваних звоника у делове манастира, већ у новом, својственом приказу.

\section{8. ЛИТЕРАТУРА}

[1] Haranglab zvonik holzglockentrum - Borut Juvanec i Andreja Benko, Факултет за архитектуру, Љубљана, 2015 године

[2] Крст у кругу - архитектура манастира у средњовековној Србији, Светлана Поповић, Републички завод за заштиту споменика културе, Београд 1994. године

[3] Архитектура Византијског света, Војислав Кораћ, Марица Шупут, Београд 1998. Године

\section{Кратка биографија:}

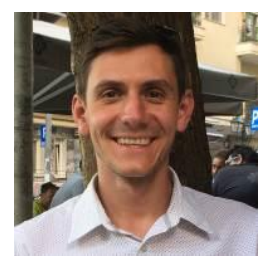

Милош Грбић рођен 1993. године у Приштини. Дипломирао је на Факултету техничких наука у Новим Саду у октобру 2017. године. Мастер рад брани на Факултету техничких наука из области Архитектонско пројектовање у октобру 2018. године. 